\title{
Perceptions and Problems of English Language and Communication Abilities: A Final Check on Thai Engineering Undergraduates
}

\author{
Krich Rajprasit ${ }^{1}$, Panadda Pratoomrat ${ }^{1} \&$ Tuntiga Wang ${ }^{1}$ \\ ${ }^{1}$ Language Center, Srinakharinwirot University, Bangkok, Thailand \\ Correspondence: Krich Rajprasit, 114 Sukhumvit, Wattana, Bangkok, Thailand. E-mail: krich@g.swu.ac.th, \\ k004_silpakorn@yahoo.com
}

Received: October 29, 2014 Accepted: December 8, 2014 Online Published: February 13, 2015

doi:10.5539/elt.v8n3p111 URL: http://dx.doi.org/10.5539/elt.v8n3p111

\begin{abstract}
English language and communication abilities are an essential part of the global engineering community. However, non-native English speaking engineers and students tend to be unable to master these skills. This study aims to gauge the perceived levels of their general English language proficiency, to explore their English communicative problems, to investigate their perceived abilities when performing English-related tasks in an engineering workplace communication situation, and to obtain feedback on student performances from English instructors in English for Specific Purposes (ESP) courses. The participants included 130 Thai undergraduate students and two English instructors at a government university. There were two instruments; a questionnaire for the students and a series of interview questions for the instructors. The results revealed that (a) although the students perceived their abilities to be at a fair level, they experienced difficulty using productive skills in English communication; (b) the English-related tasks that the students performed best and worst in were reading and writing tasks respectively; and (c) in the ESP courses, the ability of the students to use English in the 'real world' was not dramatically improved, and (d) these students also had unrealistic language learning goals. These results would benefit both ESP instructors and stakeholders in terms of increasing awareness of both language and communication problems, and designing tailor-made courses that are a perfect fit for their students with regard to the contemporary engineering community.
\end{abstract}

Keywords: English language skills, workplace communication skills, English for Specific Purposes, engineering students

\section{Introduction}

The globalization of world markets requires engineers with the capabilities of working in and with different cultures, as well as knowledge of the global markets. Thus, these engineers do not only need technical knowledge, but also the ability to express it. This means that dynamic personalities, or individuals who are skilled and efficient in multitasking (i.e. hard and soft skills) are required. This fact implies that engineers must possess communicative abilities in order to be professionally successful. This globalized era also confirms the need for individuals to develop their English language abilities as a result of increasing international interactions in both the individual and organizational contexts. Unquestionably, most international and local organizations, particularly in Asian countries, set English language proficiency as one of the primary criteria for the recruitment of new staff (Ayokanmbi, 2011; Marina \& Rajprasit, 2014; Pratoomrat \& Rajprasit, 2014).

However, the English language and communication inabilities of Asian engineers, especially at the operational level, have been addressed by engineering companies. With regard to Asian engineers in Hong Kong and Malaysia, the improvement of their speaking and writing skills are urgently required for more effective communication with business counterparts, (Quin, 2009; Singh \& Choo, 2012; Zaharim, Yusoff, Omar, Mohamed, \& Muhamad, 2008). In Thailand, novice engineers tend to lack confidence when communicating in English, especially in the oral mode (Jarupan, 2013; Kaewpet \& Sukamolson, 2011; Rajprasit, Pratoomrat, Wang, Kulsiri, \& Hemchua, 2014), and even experienced engineers have difficulties with written English, and oral workplace communication (Hart-Rawang \& Li, 2008; Joungtrakul, 2013; Laohachaiboon, 2011)

Such complaints about the lack of English communication skills among Asian engineers led to both educational institutions and stakeholders designing ESP courses and an Engineering curriculum. The most serious criticism was aimed at irrelevant instruction, in terms of language and communication skills taught in ESP courses, which 
are considered necessary for the professional workplace. In the Engineering curriculum, the development of language and communication abilities is often ignored because of the emphasis on mechanical skills (Ayokanmbi, 2011; Raina \& Pande, 2012; The Japan Times, 2009).

In order to identify the perceptions and problems experienced by undergraduate engineering students involved with local, regional, and even international labor markets, with regard to their English skills and communication abilities, this study aims to gauge the perceived level of their general English language proficiency, to explore their English communicative problems, to investigate their perceived abilities in performing English-related tasks in an engineering workplace communication situation, and to obtain feedback on student performances from English instructors in ESP courses. The results of this study would describe the current situation with regard to how engineering students can develop both abilities, and establish guidelines for a thorough revision of ESP courses (i.e. English for Engineering, English for Business Communication) to meet the expectations of the engineering workplace.

\section{Literature Review}

In this section, the competencies for global engineers, the English language and communication skills required for engineers, and workplace communication in an engineering context, are to be reviewed and discussed, based on both these concepts and related studies.

\subsection{Competencies for Global Engineers}

Globally competent engineers have to possess the abilities and attributes required for an excellent performance in a global and multicultural society, as the increased mobility of engineers poses new challenges in terms of engineering education. A call for a new pedagogical solution for the development of intercultural competencies for professional practice in the global workplace and engineering education has been addressed worldwide by a number of scholars (Ayokanmbi, 2011; Berka \& Groll, 2011; Chang, Groll, \& Hirleman, 2011; Danilova \& Pudlowski, 2007; Jesiek, Zhu, Woo, Thompson, \& Mazzurco, 2014; Missingham, 2006). ESP instruction for the engineering profession has to be consistent with the constantly changing global economy. Therefore, the global competency model is constructed to foster such a phenomenon, and the model is also integrated into the engineering curriculum with three competencies: cultural competencies (i.e. understanding and appreciating basic cultural differences and similarities around the world, together with an awareness of the factors which differentiate business practices); ethical competencies (i.e. behaving consistently in accordance with clear personal ethics and values); and communication competencies (i.e. being able to communicate effectively and successfully in the globalized society). Consistent with the scope of the present study, the third competency clarifies that engineers in the current global context will also require the ability to ascertain meaning from verbal and nonverbal languages, the willingness to accept and respond to unique and divergent styles of communication, and engage in meaningful interactions with people from other cultures (Kim, 2000).

\subsection{English Language and Communication Skills for the Engineering Profession}

The most increasing demand in the field of Engineering is the ability to master both the English language and communication skills, especially in the oral and written modes. In fact, the requirement of mastery of both English and communication skills are now necessary for this profession. This is due to a number of factors, including the nature of the profession, and the existence of globalized international interactions. As a result, global engineers, including Asian engineers, need a variety of communication skills (i.e. oral presentation, negotiation, comprehension of engineering-related information and documents, and formal correspondence, such as e-mails) in the English language. This fact implies that English language and communication skills are an essential aspect of both individual and organizational success. In the contemporary context, professionals have resorted to multi-communication (i.e. simultaneous face-to-face and electronically mediated conversations). Professionals, which include engineers, have to write e-mails and/or text messages, as well as communicate with colleagues or customers on the phone. Thus, the English language is undeniably the first language of Engineering, and a key medium to express and share technical knowledge (Ayokanmbi, 2011; Gimenez, 2014; Raina \& Pande, 2012; Thakur, Kaur, Thakur, \& Nanda, 2013; The Japan Times, 2009).

Regarding previous studies in the Asian context, English language and communication abilities play a key role in the workplace. Mohamed, Radzuan, Kassim, and Ali (2014) confirmed that oral communication skills are an advantage for Malaysian engineers in terms of the execution of daily tasks, or for the purposes of promotion and career advancement. Mehra and Virgandham (2013) also pointed out the importance of communication skills with regard to the employability of Indian engineers (i.e. oral communication skills, interpersonal skills, written communication skills, effective listening skills, and their confidence levels in terms of expressing ideas). Besides, a variety of English workplace communicative events (i.e. writing and reading e-mails, reports, and memos; 
conducting and understanding meetings, teleconferences and presentations) commonly take place in a typical Taiwanese engineering workplace (Spence \& Liu, 2013).

\subsection{Workplace Communication in the Thai Engineering Context}

In the Thai context, English language proficiency is an aspect of professional communication in various professions, including Engineering, which mainly emphasizes productive skills. Although written and oral communication skills in English are prioritized in the engineering community, experienced Thai engineers lack the skills required for technical discussions, business negotiations, and even in daily, face-to-face communication with foreign professionals. Misunderstandings and frustration may occur in any communicative event, despite the fact that these engineers possess profound technical knowledge and have valuable work experience (Hart-Rawang \& Li, 2008; Joungtrakul, 2013; Laohachaiboon, 2011). The novice engineers generally lack confidence in terms of their oral proficiency and reading skills. This is the result of failing to thoroughly prepare them for professional communication at the tertiary level (Jarupan, 2013; Rajprasit et al., 2014). According to Kaewpet and Sukamolson (2011), Thai engineering students demanded to be taught oral and written communication abilities (i.e. oral presentations, professional conversations and report writing at an organizational level, especially in the international context). These students expect that they will be required to give oral presentations and communicate with native or non-native English speakers in their future workplaces.

Based on the aforementioned situation in Thailand, the root of such problems probably originate from English language education at the tertiary level, where undergraduate students may not be educated with the language and communication skills required for the workplace communication. The solution to these problems is to identify a clear understanding of workplace language needs and communication practices, in particular at an operational level, which can be defined as entry-level for the engineering profession.

\section{Method}

\subsection{Research Questions}

According to the literature review, and as a result of the few studies available in the Thai context, the research questions are to be addressed as follows: (a) How do final-year engineering students perceive their own levels of general English language proficiency? (b) What English communicative problems do they experience? (c) How do they perceive their own abilities in terms of performing English-related tasks and communicating effectively in the professional engineering workplace? and (d) What kind of feedback did the English instructors give their students in ESP courses?

\subsection{Participants}

The total number of participants was 130, with an almost equal number of females and males, at 54 and $46 \%$, respectively. The participants consisted of fourth-year Engineering students at Thai public universities, and from the following majors: Electronics (23\%); Chemical Engineering (19\%); Civil Engineering (16\%); Biomedical Engineering (15\%); Mechanical Engineering (14\%); and Industrial Engineering (13\%). All of them took two courses of Foundation English, and two courses of ESP courses. More than half of the participants (63\%) communicated in English for at least one day a week, while the rest claimed to never use English in their daily lives. Most of them intended to take a Test of English for International Communication (TOEIC), and to apply for jobs in both local and international companies (90\%). During the last semester, almost half of the participants took English language courses (40\%). However, the English language is universally regarded by these students $(100 \%)$ as an important skill for successful job application. Furthermore, the two English instructors who taught these students both participated in individual interviews.

\subsection{Instruments}

The quantitative and qualitative approaches were employed, and two instruments were constructed. The first was a questionnaire on English language and communication skills in the engineering workplace, which was developed from related studies (Hart-Rawung \& Li, 2008; Spence \& Liu, 2013; Taillefer, 2007), and the contents were adapted to fit the context of Engineering education, and the Thai workplace. It is comprised of four parts which include the following: (a) demographic information; (b) perceived general English language proficiency; (c) problems with general English language skills, and (d) perceived abilities in performing English-related tasks in an engineering workplace communication situation. Each item was scored on a four-point scale with numerical values to indicate the level of their perceived abilities $(1=$ poor, $2=$ fair, $3=$ well, $4=$ excellent $)$ in parts two and three, and to show the frequency of English communicative problems $(1=$ never, $2=$ sometimes, 3 $=$ often, 4 = always) in part four. The second was a series of interview questions for the two English instructors, which were based on the following topics: the language abilities of students, their strengths and weaknesses in 
terms of language learning performance and achievement, and recommendations for the stakeholders of ESP courses.

For reasons of clarity, all of the questions on both instruments were translated from English into Thai, and vice versa, by two translators. Then, three Higher Education experts were asked to ascertain the content validity of the instruments, prior to the data collection process. The pilot study was conducted for reliability with ten final-year Engineering students from another university who did not participate in this study.

\subsection{Data Collection}

At the Faculty of Engineering of an unnamed Thai University, the quantitative data was collected from the participants during the last week of the second semester of the 2013 academic year. However, 130 final year students $(70 \%)$ returned the completed questionnaire. The interviews with the two English instructors were conducted a week after the questionnaire was distributed.

\subsection{Data Analysis}

The data from the questionnaire was analyzed using descriptive statistics, including frequencies, means, standard deviations, and percentages. The data from the interview were carefully coded and studied to develop the themes regarding the feedback on the performances of engineering students in their English language courses.

\section{Results}

\subsection{Perceived Levels of General English Language Proficiency among Engineering Students}

Table 1. Perceived general English language proficiency

\begin{tabular}{|c|c|c|c|}
\hline English language proficiency & Mean & S.D. & $\begin{array}{l}\text { Perceived } \\
\text { level }\end{array}$ \\
\hline \multicolumn{4}{|l|}{ Reading skills } \\
\hline 1) Reading simple words and phrases used in everyday life & 2.39 & .849 & fair \\
\hline 2) Reading short, simple texts for the gist or specific information & 2.28 & .835 & fair \\
\hline $\begin{array}{l}\text { 3. Reading texts written in everyday language, or relative to my studies, at a } \\
\text { rather slow pace }\end{array}$ & 2.15 & .801 & fair \\
\hline $\begin{array}{l}\text { 4) Reading articles or reports expressing a particular point of view, as long as } \\
\text { there is adequate time }\end{array}$ & 2.04 & .772 & fair \\
\hline $\begin{array}{l}\text { 5) Reading longer, complex, and more specialized texts, and able to appreciate } \\
\text { differences in style, in a reasonable time frame }\end{array}$ & 1.84 & .758 & fair \\
\hline $\begin{array}{l}\text { 6) Reading any type of text easily, even abstract or complex documents, and } \\
\text { able to appreciate subtle distinctions of style, and implicit and explicit } \\
\text { meanings }\end{array}$ & 1.75 & .727 & poor \\
\hline Overall & 2.09 & .631 & fair \\
\hline \multicolumn{4}{|l|}{ Listening skills } \\
\hline 1) Understanding words, and basic, familiar expressions in a limited context & 2.31 & .756 & fair \\
\hline $\begin{array}{l}\text { 2) Understanding expressions and common vocabulary relative to my } \\
\text { immediate environment }\end{array}$ & 2.21 & .851 & fair \\
\hline $\begin{array}{l}\text { 3) Understanding key points in clear, standard speech when people speak } \\
\text { slowly on familiar topics }\end{array}$ & 2.21 & .814 & fair \\
\hline $\begin{array}{l}\text { 4) Understanding longer talks and following complex lines of argument on } \\
\text { familiar topics; an understanding of most news programs in standard dialect }\end{array}$ & 1.75 & .705 & poor \\
\hline $\begin{array}{l}\text { 5) Understanding extended speech, even when it is not clearly structured, and } \\
\text { TV programs, with relative ease }\end{array}$ & 1.80 & .730 & fair \\
\hline $\begin{array}{l}\text { 6) Understanding any kind of spoken language, whether broadcast live or } \\
\text { prerecorded, as long as I have time to become familiar with a particular accent }\end{array}$ & 1.87 & .801 & fair \\
\hline Overall & 2.02 & .622 & fair \\
\hline
\end{tabular}


Table 1. Perceived general English language proficiency (continued)

\begin{tabular}{lllll}
\hline Writing skills & & & \\
1) Writing notes on short and specific pieces of information & 2.02 & .787 & fair \\
2) Writing short and simple notes and messages & 2.23 & .840 & fair \\
3) Writing coherent texts or notes on familiar subjects & 2.05 & .786 & fair \\
4) Writing clear and detailed texts, reports and essays on topics in my field & 1.65 & .679 & poor \\
$\begin{array}{l}\text { 5) Writing clear, well-structured texts, and developing my point of view on } \\
\text { complex subjects }\end{array}$ & 1.68 & .696 & poor \\
$\begin{array}{lllll}\text { 6) Writing clear, smoothly flowing and stylistically appropriate prose; able to } \\
\text { write summaries or critical reviews }\end{array}$ & & & \\
\hline Overall & & .710 & poor \\
\hline
\end{tabular}

Speaking skills

1) Saying basic expressions, phrases and asking simple questions on familiar subjects, as long as my interlocutor is willing to help me understand and express myself

2) Responding to familiar topics, such as describing my university course in simple terms, and carrying on a very limited conversation

$2.29 \quad .783$ fair

3) Generally explaining my opinions or projects; spontaneously participating in conversations on familiar topics

4) Expressing myself clearly and in detail, actively participating in conversations on topics relative to my interests; spontaneously communicating with a native speaker

5) Describing complex subjects clearly and in an appropriate manner; expressing myself spontaneously, clearly and easily in either professional or social contexts

6) Describing or arguing complex subjects clearly and easily and in an appropriate manner; expressing myself in any situation in standard, idiomatic language with appropriate nuances; correcting my mistakes in a natural way

(183.

$1.98 \quad 802 \quad$ fair

$1.79 \quad .747$ fair

which draws little notice

\begin{tabular}{llll}
\hline Overall & 1.87 & .810 & fair \\
\hline Overall English language proficiency & 1.97 & .578 & fair \\
\hline
\end{tabular}

Note: In each skill, individual items range from basic to advanced levels.

According to Table 1, even though final-year engineering students generally perceived their English language proficiency at a fair level, productive skills, such as speaking and writing, seemed to be the most difficult aspect of English communication for them (Mean $=1.87$, and 1.88, respectively). Of all the four skills, the students were the worst at speaking. Considering the six individual items in the speaking section, which ranged from the basic to advanced levels, they could use basic expressions and phrases, as well as ask simple questions regarding similar subjects. However, they tended to speak English poorly, even at the more advanced levels. Another skill that likely caused these students some difficulties was writing. Similarly, the students also perceived their writing at a poor level, especially when given more complicated tasks. 


\subsection{The English Communicative Problems Experienced by Students}

Table 2. Problems regarding general English language skills

\begin{tabular}{llll}
\hline English communicative problems & Mean & S.D. & Perceived level \\
\hline Reading skills & & & \\
1) Inability to find the main idea(s) & 2.43 & .835 & sometimes \\
2) Inability to use scanning technique & 2.57 & .777 & often \\
3) Inability to use detailed reading technique & 2.32 & .749 & sometimes \\
4) Inability to use skimming technique & 2.46 & .695 & sometimes \\
5) Inability to guess meaning from the context & 2.51 & .673 & sometimes \\
6) Inability to identify the tone of passages or articles & 2.35 & .714 & sometimes \\
7) Inability to understand technical terms in passages or articles & 2.55 & .671 & often \\
8) Inability to understand whole passages or articles & 2.35 & .701 & sometimes \\
\hline Overall & 2.36 & .715 & sometimes
\end{tabular}

Listening skills

\begin{tabular}{llll} 
1) Inability to understand English presentations and/or discussions & 2.52 & .696 & often \\
2) Inability to understand long conversations & 2.65 & .701 & often \\
3) Inability to understand any information from speaker(s) & 2.45 & .716 & sometimes \\
\hline Overall & 2.54 & .779 & often \\
\hline Writing skills & & & \\
1) Inability to use punctuation correctly & 2.25 & .719 & sometimes \\
2) Inability to spell words correctly & 2.37 & .684 & sometimes \\
3) Inability to write more complicated structures & 2.67 & .675 & sometimes \\
4) Inability to use vocabulary in different contexts & 2.50 & .600 & sometimes \\
5) Inability to write a paragraph or more & 2.42 & .796 & sometimes \\
6) Inability to express opinions effectively when writing & 2.54 & .738 & often \\
7) Inability to convey messages to readers & 2.51 & .696 & sometimes \\
\hline Overall & 2.45 & .759 & sometimes \\
\hline Speaking skills & & & \\
1) Inability to make an oral presentations & 2.53 & .891 & often \\
2) Inability to construct oral sentences in a limited time & 2.59 & .679 & often \\
3) Anxiety related to miscommunication & 2.61 & .821 & often \\
4) Limited English vocabulary & 2.64 & .747 & often \\
5) Inability to communicate properly & 2.66 & .894 & often \\
6) Inability to pronounce English clearly and correctly & 2.52 & .770 & often \\
\hline Overall & 2.58 & .724 & often \\
\hline Overall English communicative problems & 2.45 & .706 & sometimes \\
\hline
\end{tabular}

In Table 2, the problems regarding English communication were examined. Even though these students sometimes had more general problems, they often had more specific difficulties with listening and speaking, compared to all of the others (Mean $=2.54$, and 2.58, respectively.) 


\subsection{Perceived Abilities When Performing English-Related Tasks in the Engineering Workplace}

Table 3. Perceived abilities in performing English-related tasks in the engineering workplace

\begin{tabular}{llll}
\hline English-related tasks in workplace communication & Mean & S.D. & Perceived level \\
\hline English-related reading tasks & & & \\
1) Instructions/recommendations & 2.42 & 0.644 & fair \\
2) Manuals & 2.38 & 0.601 & fair \\
3) Project reports & 2.38 & 0.601 & fair \\
4) Inter-office documents & 2.35 & 0.553 & fair \\
5) Engineering-related articles & 2.33 & 0.602 & fair \\
\hline Overall & 2.37 & 0.479 & fair \\
\hline English-related listening tasks & & & \\
1) Understanding instructions/recommendations & 2.34 & 0.604 & fair \\
2) Understanding the core content when attending international & 2.12 & 0.618 & fair \\
seminars, meetings or conferences & & & \\
\hline Overall & 2.23 & 0.557 & fair \\
\hline English-related writing tasks & & & \\
1) E-mail & 2.20 & 0.644 & fair \\
2) Report/Diary & 2.22 & 0.685 & fair \\
3) Project proposal & 2.18 & 0.603 & fair \\
4) Project report & 2.09 & 0.664 & fair \\
5) Business letter & 1.93 & 0.673 & fair \\
6) Presentation slide & 2.23 & 0.699 & fair \\
\hline Overall & 2.14 & 0.539 & fair \\
\hline English-related speaking tasks & & & \\
1) Oral presentation & 2.25 & 0.686 & fair \\
2) Meeting/seminar & 2.08 & 0.671 & fair \\
3) Routine work & 2.17 & 0.672 & fair \\
4) Telephone & 2.18 & 0.644 & fair \\
5) Informal and social conversations & 2.44 & 0.682 & fair \\
\hline Overall & 2.23 & 0.557 & fair \\
\hline Overall English-related tasks & 2.24 & 0.458 & fair \\
\hline & & & \\
\hline
\end{tabular}

In Table 3, the abilities of the participants to perform English-related tasks in the engineering workplace were identified. Generally, they perceived their abilities at a fair level, the English-related tasks that they performed worst in were writing tasks, and they performed best at English-related reading tasks.

\subsection{The Feedback from English Instructors Regarding Student Performance}

\subsubsection{The Language Abilities of the Students}

The ability of the engineering students in the two ESP courses, their ability to use the English language in a less-restricted environment cannot be accurately quantified. Their ability to use English in the 'real world' was not dramatically improved by taking these courses. Of the four language skills, their reading skills were the best and their ability to engage in small talk with instructors (e.g. asking questions) was rated as satisfactory. 


\subsubsection{The Strengths of Students in ESP Courses}

The students demonstrated their strengths when following a structured set of tasks (e.g. listening practice and vocabulary exercises) which led to restricted practice towards the end of each lesson. The restricted practice was usually in the form of a role-play. With this in mind, all of the lessons to follow were in the same format. Therefore, those students were more motivated by knowing that each of the tasks they were required to complete was essential in order to reach the final goal (a restricted practice). The students responded most favorably to working in groups, as they come from a particularly close faculty, and as a result group work was incorporated into these lessons wherever possible, in order to increase both motivation and productivity.

\subsubsection{The Weaknesses of Students in ESP Courses}

In general, the students were most comfortable following a set of defined instructions. When they were asked to do free practice (e.g. creating their own original role-plays), most students did not have the ability or creativity to achieve this, and as a result, the exercise was a failure. Some students tended to have unrealistic goals with regards to learning English. For example, they expected to use these classes to prepare their resumes and to review frequently asked questions in job interviews. These are unrealistic goals, considering the fact that conducting a basic conversation in English is a struggle for many of these students. In addition, many of them seemed to consider their grades or scores to be far more important than any of the learning outcomes. This detracted from their overall achievement and level of satisfaction with the courses.

\section{Discussion}

The aforementioned results were discussed as follows: First, Thai engineering students perceived their levels of general English language proficiency at a fair level, and claimed that speaking and writing skills, regarded as key language skills for success in their profession, were likely to be problematic for them. The findings confirmed the results of previous studies about Thai students and engineers, their English language abilities, and the urgent need for English language improvement which has been necessary for almost a decade. It seems that in spite of learning language from the primary education, many Thais have not reached a competent or proficient level, and their inability of English language and communication is an unsolvable problem. (Hart-Rawang \& Li, 2008; Jarupan, 2013; Joungtrakul, 2013; Kaewpet \& Sukamolson, 2011; Laohachaiboon, 2011; Rajprasit et al., 2014).

Second, the communication abilities of Thai engineers performing English-related communication tasks in the workplace are also limited, particularly in the oral and written modes. Due to an increase in international interactions and business operations, the engineering profession has to be ready for change, and engineering curriculum should not take this for granted anymore (Ayokanmbi, 2011; Gimenez, 2014; Mehra \& Virgandham, 2013; Radzuan, Kassim, \& Ali, 2014; Raina \& Pande, 2012; Spence \& Liu, 2013; Thakur et al., 2013). Besides, the students that tend to have difficulties with English communication in the classroom may also experience difficulty in the potential workplaces. To solve such a problem, integrating the realistic communicative situations into ESP courses, and creating workplace environment which always challenges the language users (i.e. problematic and non-problematic communicative situations) might lead to a right direction to prepare those students for the future workplace (Marina \& Rajprasit, 2014).

Third, even though complaints regarding the English communication inabilities of non-English speaking, tertiary-level students have been made worldwide, including Thailand, the feedback provided by language instructors on the performances of engineering students should be considered as these instructors have eye-witnessed the learning performances of these students (Chang, Groll, \& Hirleman, 2011; Missingham, 2006). The determination of these students, as well as their creativity and contributions to ESP courses, are key factors which help students to develop their own language and communication abilities. Without these key factors, the opportunity for these students to reach a level of 'satisfactory' is extremely difficult. In addition, teachers and stakeholders need to step out of the academic realm and into the professional world to determine which abilities are actually essential for successful professional communication.

Even though this study is limited to Thai engineering students in a government university, the results may provide some suggestions for ESP instruction for non-native English speaking engineering undergraduates. First, ESP courses are regarded to be suitable for those students who have already reached a certain proficiency in English (generally, the intermediate level). However, many of them are still at an elementary level, especially with regard to speaking and listening skills. Therefore, ESP courses, in their true form, should be reserved only for the very best students in each year group, while the remainder should instead be considered for additional speaking and listening practice instead. Second, tailor-made ESP courses are designed to suit the needs and the natures of Engineering students, especially non-native English speakers, as they would specifically solve the problems of the language and communication found in the present study. Third, if the course is to remain 
mandatory for everyone, the students should be streamed according to their ability, rather than by their engineering major. When classes are divided by major, it leads to groups of very mixed ability. If classes were streamed according to ability, native-speaking instructors could take the most able classes, leaving better-equipped Thai instructors to help the weaker students.

\section{Conclusion}

This study aimed to identify the perceptions of Thai engineering students in a government university, and the problems they experienced with both the English language and their communication abilities. In spite of the necessity of such abilities in the contemporary engineering community, final-year students may not meet the expectations of their future workplaces. They seemed to experience some difficulties with workplace communication. Moreover, the feedback from their instructors reflected the fact that these students urgently required the improvement of both of these abilities for reasons of effective professional communication.

Despite providing results from a small scale, the study reveals the unsolvable problem deeply rooted in the English language education in the Thai context, and such problem may not be similar to that of other Asian countries. For further studies, developing ESP courses for engineering profession combining specific workplace communicative situations is in need. Moreover, an in-depth investigation into the Engineering communicative situations and behaviors should be conducted in both local and international companies, and also in each engineering field. To do so, students will possibly improve the language and communication abilities, especially for non-native English speakers including Thais. Besides, certain regular engineering communicative situations (i.e. oral presentations, professional conversations and report writing) should be in a focus.

\section{Acknowledgements}

The researchers would like to thank the International College for Sustainability Studies at Srinakharinwirot University for granting research funds. We deeply express our grateful thanks to reviewers for their suggestions which made this research paper possible.

\section{References}

Ayokanmbi, F. M. (2011). Competencies for global engineers and technologists. Journal of Industrial technology, 27(1), 1-6.

Berka, S., \& Groll, E. (2011). Bridging the languages with engineering: Editors' introduction. Online Journal for Global Engineering Education, 6(1), 1-2.

Chang, Y., Groll, E., \& Hirleman, E. D. (2011). Best of both worlds: Foreign language preparation for Purdue University's undergraduate global engineering education program. Online Journal for Global Engineering Education, 6(1), 1-12.

Danilova, E. A., \& Pudlowski, Z. J. (2007). Important considerations in improving the acquisition of communication skills by engineers. Global Journal of Engineering Education, 11(2), 153-161.

Gimenez, J. (2014). Multi-communication and the business English class: Research meets pedagogy. English for Specific Purposes, 35, 1-16. http://dx.doi.org/10.1016/j.esp.2013.11.002

Hart-Rawung, P., \& Li, L. (2008). Globalization and business communication: English communication skills for Thaiautomotive engineers. World Academy of Science, Engineering, and Technology, 24, 320-330.

Jarupan, S. (2013). The English oral communication competency of Thai engineering students. International Journal of Scientific and Research Publications, 3(3), 1-9.

Jesiek, B. K., Zhu, Q., Woo, S. E., Thompson, J., \& Mazzurco, A. (2014). Global engineering competency in context: Situations and behaviors. Online Journal for Global Engineering Education, 8(1), 1-14. Retrieved from http://digitalcommons.uri.edu/ojgee/vol8/iss1/1

Joungtrakul, N. (2013). Thai engineers' readiness to cope with the free flow of skilled labor in the ASEAN Economic Community. HRD Journal, 4(1), 6-21.

Kaewpet, C., \& Sukamolson, S. (2011). A sociolinguistic approach to oral and written communication for engineering students. Asian Social Science, 7(10), 183-187. http://dx.doi.org/10.5539/ass.v7n10p183

Kim, Y. Y. (2000). Becoming intercultural: An integrative theory of communication and cross-cultural adaptation (p. 8). Sage Publications.

Laohachaiboon, S. (2011). Intercultural communication obstacles in a Japanese company: a case study into cross-cultural effect and difficulties in English communication of Thai employees at Toyota Tsusho 
(Thailand) Co., Ltd. (Unpublished master's thesis). Thammasart University, Bangkok, Thailand.

Marina, O., \& Rajprasit, K. (2014). Investigating the impact of personality factors on perceived communication mobility of non-native English speaking Thai professionals in international companies. PASAA, 47, 61-96.

Mehra, D., \& Virgandham, V. (2013). Communication skills for enhanced employability of engineers: A review of literature. The Confluence Journal, 3, 70-76. Retrieved from http://www.researchgate.net/publication/ 258374680_Communication_Skills_for_Enhanced_Employability_of_Engineers_A_review_of_literature

Missingham, D. (2006). The integration of professional communication skills into engineering education. Proc. EDU-COM 2006 International Conference on Engagement and Empowerment: New Opportunities for Growth in Higher Education. Retrieved from http://www.ro.ecu.edu.au/cgi/viewcontent.cgi?article=1090\& context=ceducom

Mohamed, A. A., Radzuan, N. R. M., Kassim, H., \& Ali, M. M. A. (2014). Conceptualizing English workplace communication needs of professional engineers: The challenges for English language tertiary educators. International Journal of Contemporary Business Management, 1(1), 1-9.

Pratoomrat, P., \& Rajprasit, K. (2014). Exploring current situations and corporate needs of English language use in workplace: Thai professionals' voices to Tertiary Education. Veridian E-Journal, 7(1), 28-47.

Qian, D. (2009). Using English for Workplace Communication: A Study of Novice Professionals. Retrieved from http://www.engl.polyu.edu.hk/rcpce/documents/LanguageForProfessionalCommunication.pdf

Raina, R., \& Pande, N. (2012). Communication competence of Indian engineers in IT \& ITeS sector. The Indian Journal of Industrial Relations, 47(3), 511-526.

Rajprasit, K., Pratoomrat, P., Wang, T., Kulsiri, W., \& Hemchua, S. (2014). Use of the English language prior to and during employment: Experiences and needs of Thai novice engineers. Global Journal of Engineering Education, 16(1), 27-33.

Savignon, S. J. (1997). Communicative competence: Theory and Practice (2nd ed.). New York: McGraw Hill.

Singh, M. K. M., \& Choo, J. C. S. (2012). Manufacturing industry employers' perception of graduates' English language skills proficiency. International Journal of Applied Linguistics \& English Literature, 1(4), 114-124. http://dx.doi.org/10.7575/ijalel.v.1n.4p.114

Spence, P., \& Liu, G. (2013). Engineering English and the high-tech industry: A case study of an English needs analysis of process integration engineers at a semiconductor manufacturing company in Taiwan. English for SpecificPurposes, 32, 97-109. http://dx.doi.org/10.1016/j.esp.2012.11.003

Taillefer, G. F. (2007). The professional language needs of economics graduates: assessment and perspectives in the French context. English for Specific Purposes, 26(2), 135-155. http://dx.doi.org/10.1016/j.esp.2006.06.003

Thakur, S., Kaur, S., Thakur, P. V., \& Nanda, D. R. (2013). English teaching to engineering students difficulties and solutions. Journal of Literature, Languages and Linguistics, 2, 55-59.

The Japan Times. (2009). Japan Times Forum on English Education: Engineers Must Have English Skills to Succeed. Retrieved from http://www.sci.kanagawa-u.ac.jp/pdf/2009_times01.pdf

Zaharim, A., Yusoff, Y., Omar, M. Z., Mohamed, A., \& Muhamad, N. (2008). Engineering employability skills required by employers in Asia. Proceedings of 6th WSEAS International Conference on Engineering Education (pp. 195-201). Retrieved from http://www.wseas.us/elibrary/conferences/2009/rodos/EDU/ EDU30.pdf

\section{Copyrights}

Copyright for this article is retained by the author(s), with first publication rights granted to the journal.

This is an open-access article distributed under the terms and conditions of the Creative Commons Attribution license (http://creativecommons.org/licenses/by/3.0/). 